\title{
Short Communication: Species identity and taxonomical position of selected species of Annonaceae based on trnL molecular marker
}

\author{
DEWI AYU LESTARI ${ }^{1, \vartheta}$, RODIYATI AZRIANINGSIH ${ }^{2, \vee v}$ \\ 'Purwodadi Botanic Garden, Research Center for Plant Conservation and Botanic Garden, Indonesian Institute of Sciences. Jl. Raya Surabaya-Malang \\ Km. 65, Purwodadi, Pasuruan 67163, East Java, Indonesia. Tel./fax.: +62-343-615033, ’email: chunyang.dee@gmail.com \\ ${ }^{2}$ Department of Biology, Faculty of Mathematics and Natural Sciences, Brawijaya University, Jl. Veteran Malang 65133, East Java, Indonesia. \\ Tel.: +62-341-554403, "“email: rodiyati@ub.ac.id
}

Manuscript received: 17 January 2019. Revision accepted: 16 March 2019.

\begin{abstract}
Lestari DA, Azrianingsih R. 2019. Species identity and taxonomical position of selected species of Annonaceae based on trnL molecular marker. Biodiversitas 20: 1012-1019. Identification based on morphological characters could be difficult when some characters are not visible. The absence of some morphological characters could effect for identification of species identity and taxonomical position of the species. Confirmation by the DNA data is needed to support species identification. The sequence was used in this research is $\operatorname{trn} \mathrm{L}$ intron as non-coding sequence DNA, based on chloroplast DNA. The research aimed to estimate of species identity and determine of taxonomical position of species of Annonaceae based on $\operatorname{trn} \mathrm{L}$ sequences. Methods were used through steps of DNA extraction, DNA amplification, DNA sequencing, and data analysis to selected species of Annonaceae from Purwodadi Botanic Garden (PBG), the trn $\mathrm{L}$ intron sequences of 10 Annonaceae species from GenBank database and two species of Magnoliaceae as outgroup. Results showed that $\operatorname{trn} \mathrm{L}$ sequence as non-coding gene explains the different groupings with the previous groupings in Annonaceae to this observed species. $\operatorname{trn} \mathrm{L}$ sequence can estimate of species identity as much as $30 \%$, caused by changes of nucleotide bases from mutation and missing data. Polymorphism of DNA sequences showed that $61.18 \%$ sites as conserved region, $24.05 \%$ sites as polymorphic variation and $14.76 \%$ sites as alignment gaps. Oxymitra sp. is in group (monophyletic) with Mitrephora javanica because they are genetically in close relationship (Uvariae tribes and Annonoideae sub-family), Popowia sp. is in group with Orophea enterocarpa, because they are genetically in close relationship (Miliuseae tribes and Malmeoideae sub-family).
\end{abstract}

Keywords: Annonaceae, identity, sequence, taxonomical positions, $\operatorname{trn} \mathrm{L}$

\section{INTRODUCTION}

Annonaceae (custard apple family) is one of the most primitive families of the Angiosperm (Hutchinson 1969) that comprises about 120-130 genera and 2500 species (van Heusden 1992). Based on APG system (Angiosperm Phylogeny Group system)) (1998), APG II system (2003) and APG III system (2009), Annonaceae was placed most closely related to the small Magnoliid family Eupomatiaceae. This family has four subfamilies, there are Anaxagoreoideae, Ambavioideae, Annonoideae, and Malmeoideae. Together, Annonoideae and Malmeoideae comprise the majority of the species and each is further subdivided into some number of tribes. Subdivision of Annonaceae has been problematic, and their classification is far from being comparable with each other, although this family is well characterized and contain valuable elements. Difficulties were shown for classification on tribes level in Asiatic-Australian genera (Kessler 1995; Lestari et al. 2017). Chatrou et al. (2012) was an amendment for Annonoideae and new subfamilies, and some of tribes classification were recognized.

At least 56 species of Annonaceae have been conserved in Purwodadi Botanic Garden (PBG). Some individuals in PBG have not been identified because they have problems in the appearance of flower and fruit. The appearance of flowers never succeeded in becoming a fruit. Unconditional flowering and non-concurrent anthesis between male and female flowers are the main factors that were affecting the reproduction of Annonaceae (Handayani 2016). This problem effects the identification of unidentified species. Whereas, species of Annonaceae can be classified based on morphological characters (Maas and Westra 1984; Westra 1985; Morawetz and Le Thomas 1988; van Heusden 1992; van Setten and Koek-Noorman 1992; Johnson and Murray 1995; Doyle and Le Thomas 1996; Svoma 1998; Johnson 2003; Maas et al. 2003; Tsou and Johnson 2003; Scharaschkin and Doyle 2005, 2006; Su and Saunders 2006; Maas et al. 2007; Couvreur 2009; Huysmans et al. 2010; Surveswaran et al. 2010; Weerasooriya and Saunders 2010a). So that, the identity of species become unclear, and the taxonomical position of this species is doubtful, misidentified and misnamed (Kwon et al. 2016).

Identification keys merely using morphology character could be difficult to use when some features are not visible. Thus, the absence of some morphological features could make the identification impossible (Amandita 2015). Based on these problems, it is needed to confirm the morphological identification by DNA sequence or gene. The emergence of molecular approaches has led to the 
formation of several streams within systematics, such as elucidation of phylogenetic relationships and descriptive studies which are combining phylogenetically and phenotypically markers (Stackebrandt and Goebel 1994). Most of species within Annonaceae was confirmed by coding or non-coding of DNA sequence. Molecular phylogenetic analysis of Annonaceae species were studied, such as Zhou et al. (2009; 2010) in Uvaria based on sequences of four plastid DNA regions such as matK, $p s b \mathrm{~A}-t r n \mathrm{H}$ spacer, $r b c \mathrm{~L}$ and $t r n \mathrm{~L}-\mathrm{F}$, Tang et al. (2015a; 2015 b) in phylogenetic reconstruction of Goniothalamus was used nine cpDNA regions, Li et al. (2015) in generic delimitation of Disepalum using four chloroplast and two nuclear DNA regions, Chaowasku and Keßler (2013) in molecular phylogeny of Miliusa with combination of seven plastid markers, Lestari et al. (2018) in phylogenetic analysis of Annonaceae species collections using three chloroplast DNA, Chatrou et al. (2012) in phylogenetic analysis using DNA molecular marker was known classification of subfamily and new tribes in Annonaceae, and the other studies. Confirmation of species identity on Annonaceae species collections from PBG uses trnL intron as one of the non-coding sequence DNA, located on chloroplast DNA (cp-DNA). Uses of this sequence is combined with the other sequences (Chaowasku and Keßler 2013; Chatrou et al. 2012). Applications of this sequence are assumed to be conserved in its evolution in terms of nucleotide substitution with very little rearrangements which permit the molecule to be used in resolving phylogenetic relationships especially at deep levels of evolution (Patwardhan et al. 2014).

The chloroplast of $\operatorname{trn} \mathrm{L}$ (UAA) intron may represent a good target region for many purposes. Its sequences have been widely used for reconstructing phylogenies between closely related species or for identifying plant species. It does not represent the most variable non-coding region of chloroplast DNA, but it bears some unique advantages. Universal primers, subsequently extensively used, have faster rates of evolution as marker for mainly in phylogenetic than the other sequences, evolutionary and taxonomic studies among closely related genera and species, at lower taxonomic level and detecting species level variations (Procaccini et al. 1999; Tsai et al. 2006; Taberlet et al. 2007). The $t r n \mathrm{~L}$ gene is part of $t r n \mathrm{~L}-\mathrm{F}$ region of chloroplast genome that split by group I intron, the intergenic spacer and $t r n F$ exons and is co-transcribed. This gene can be implied for phylogenetics reconstruction in Dipterocarpaceae (Yulita 2013), consensus between the morphological and molecular character in Pandanus (Rachma et al. 2017), genetic variation in Amorphophallus meulleri (Wahyudi et al. 2013), suitable for phylogenetic analysis of Cinnamomum spp. (Kojoma et al. 2002), genetic variability among porang populations in Eastern Java (Rosidiani 2011) to the identification of orchid species (Kishor and Sharma 2018). The research aimed to estimate species identity and to determine the taxonomical position of selected Annonaceae species based on $\operatorname{trn} \mathrm{L}$ sequence.

\section{MATERIALS AND METHODS}

\section{Study area}

The research was conducted in November 2016 February 2017 at the Laboratory of Plant Physiology, Tissue Culture, and Microtechnic, Department of Biology, Faculty of Mathematics and Natural Sciences, Brawijaya University, Malang, and PBG - Research Center for Plant Conservation and Botanic Garden, Indonesian Institute of Sciences, Pasuruan, East Java. Materials used were young leaf samples of Annonaceae species collections of PBG as much 5 species (Figure 1) and the trnL intron sequences of 10 Annonaceae species were obtained from the GenBank database (http: //www.ncbi.nlm.nih.gov/) with 2 species from Magnoliaceae as the outgroup (Table 1). Magnoliaceae was chosen as the outgroup because Magnoliaceae was the closest sister of Annonaceae. Young leaf material samples were obtained further extracted through steps of DNA extraction, DNA amplification through PCR technique, DNA sequencing, and data analysis. The trn $\mathrm{L}$ intron sequences of 10 Annonaceae species from GenBank were analyzed together with DNA sequences of 5 Annonaceae species from PBG.

Table 1. Material samples of Annonaceae species were observed and outgroup

\begin{tabular}{|c|c|c|}
\hline Species & No voucher & Subfamily \\
\hline $\begin{array}{l}\text { Fissistigma latifolium } \\
\text { (Dunal) Merr. }\end{array}$ & P19820362 & Annonoideae \\
\hline Mitrephora javanica Backer & P19850167 & Malmeoideae \\
\hline Mitrephora polypyrena Miq. & P19811116 & Malmeoideae \\
\hline Oxymitra sp. & P19850160 & Annonoideae \\
\hline Popowia sp. & $\begin{array}{l}\text { P19790732 } \\
\text { Genbank } \\
\text { accession } \\
\text { number }\end{array}$ & Malmeoideae \\
\hline Anaxagorea javanica Blume & AY580031.1 & Anaxagoreoideae \\
\hline $\begin{array}{l}\text { Anaxagorea luzonensis } \\
\text { A.Gray }\end{array}$ & AY580032.1 & Anaxagoreoideae \\
\hline Annona glabra $\mathrm{L}$. & KX663998.1 & Annonoideae \\
\hline Annona montana Macfad. & KX663995.1 & Annonoideae \\
\hline Annona muricata $\mathrm{L}$. & KX663992.1 & Annonoideae \\
\hline $\begin{array}{l}\text { Artabotrys hexapetalus } \\
\text { (L.f.) Bhandari }\end{array}$ & AY231286.1 & Annonoideae \\
\hline $\begin{array}{l}\text { Cananga odorata (Lam.) } \\
\text { Hook.f. \& Thomson }\end{array}$ & KF586710.1 & Ambavioideae \\
\hline $\begin{array}{l}\text { Goniothalamus } \\
\text { macrophyllus (Blume) }\end{array}$ & EU249789.1 & Annonoideae \\
\hline Hook.f. \& Thomson & & \\
\hline $\begin{array}{l}\text { Goniothalamus malayanus } \\
\text { Hook.f. \& Thomson }\end{array}$ & EU249796.1 & Annonoideae \\
\hline $\begin{array}{l}\text { Magnolia candolli (Blume) } \\
\text { H.Keng* }\end{array}$ & P19821171 & - \\
\hline Michelia champaca L.* & P1997110091 & - \\
\hline $\begin{array}{l}\text { Orophea enterocarpa } \\
\text { Maingay ex. Hook.f. \& } \\
\text { Thomson }\end{array}$ & EU249781.1 & Malmeoideae \\
\hline
\end{tabular}

Note: *indicated as outgroup 


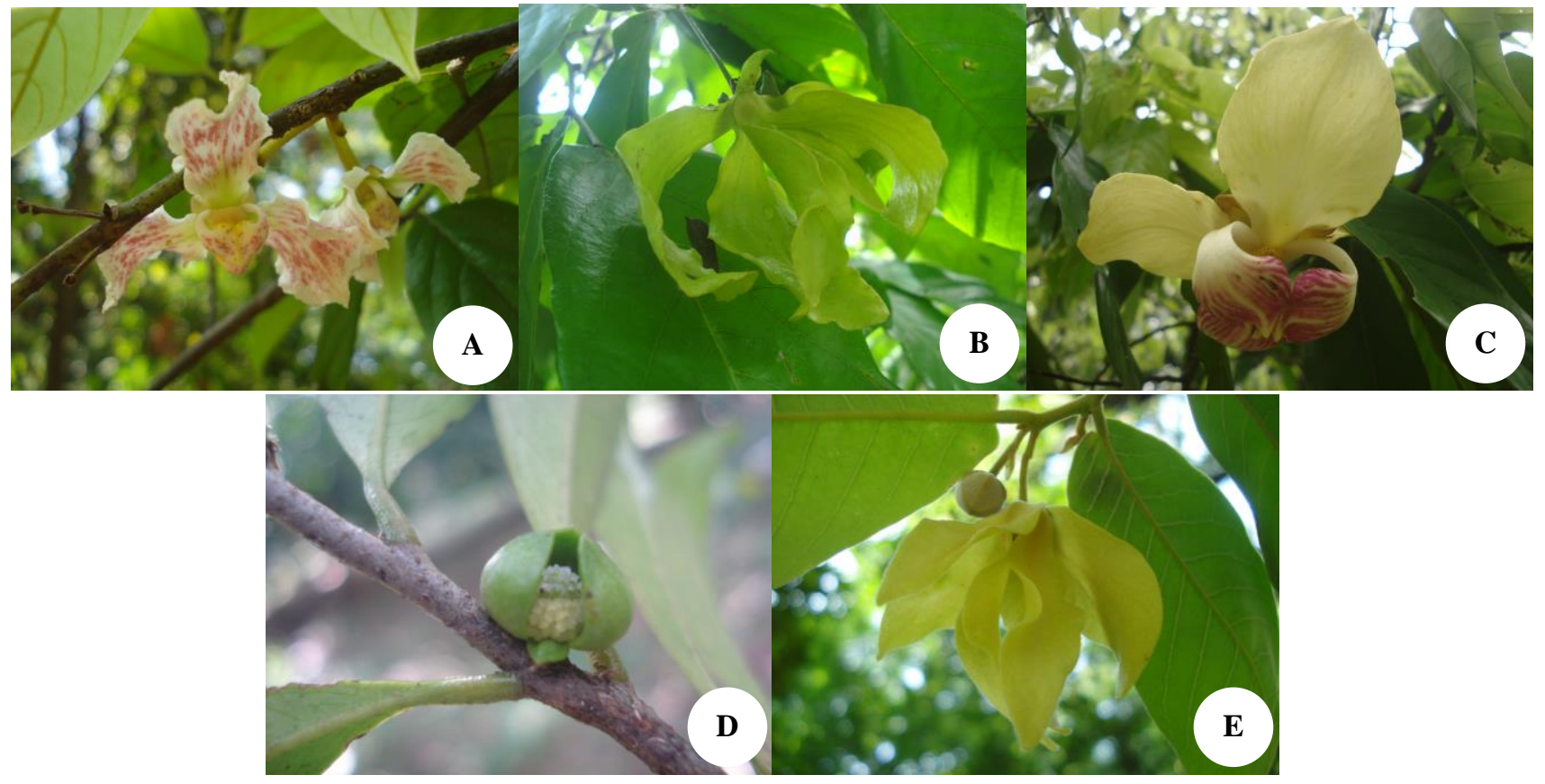

Figure 1. Material samples of selected species of Annonaceae. A. Mitrephora javanica, B. Fissistigma latifolium, C. Mitrephora polypyrena, D. Popowia sp.*), E. Oxymitra sp.*) ${ }^{*}$ species identity was confirmed in this study)

\section{Procedures}

DNA extraction

DNA extraction on material samples from PBG was using CTAB (Cethyl Trimethyl Ammonium Bromide) method (Fatchiyah et al. 2011). Long-term use of DNA was stored at $-20^{\circ} \mathrm{C}$.

\section{DNA amplification}

DNA amplification was using the molecular marker of trnL (non-coding DNA), in each of the DNA samples. Each $10 \mu \mathrm{L}$ of solution (Fatchiyah et al. 2011), mixed aquabidest $\left(\mathrm{ddH}_{2} \mathrm{O}\right)$ of $2 \mu \mathrm{L}$, PCR mix solution $(2 \mathrm{x}$ concentration) of $5 \mu \mathrm{L}$, forward molecular marker (@10 pmole) of $1 \mu \mathrm{L}$, reverse molecular marker (@10 pmole) of $1 \mu \mathrm{L}$ and $1 \mu \mathrm{L}$ DNA samples. The samples then spin-down for 3 seconds and fed into the PCR thermal cycle tool for amplification. Annealing program on trn $\mathrm{L}$ molecular marker was initial denaturation at $94^{\circ} \mathrm{C}$ for 5 minutes; denaturation at $94^{\circ} \mathrm{C}$ for 30 seconds, annealing at $61^{\circ} \mathrm{C}$ for 30 seconds, extension at $72^{\circ} \mathrm{C}$ for 30 seconds (repeated by 35 cycles); final extension at $72^{\circ} \mathrm{C}$ for 10 minutes with sequence molecular marker (F) 5' CGAAATCGGTAGACGCTACG-3' and (R) 5'GGGGATAGAGGGACTTGAAC -3' (Rachma et al. 2017).

\section{DNA sequencing}

Sequencing was done to know DNA sequences from amplified DNA. DNA samples were sequenced with automatic sequencer machine in 1st Base Laboratory, Malaysia.

\section{Data analysis}

Sequences data then evaluated by ABI sequence scanner program to know quality of the DNA sequence. Only good quality sequence DNA can be analyzed further. DNA sequence with good quality then tested homology with BLAST on NCBI (a homology level of $\geq 92 \%$ ). The result from BLAST was to use estimation of species identity from PBG plant species. Taxonomical position of the species from PBG and 10 Annonaceae species from GenBank with outgroup can be showed by phylogenetic tree (cladogram) was obtained by alignment using Clustal $\mathrm{W}$ program and further analysed based on Kimura 2 parameter (K2P) with algorithm methods of Maximum Parsimony (MP) using MEGA 5 program (Pathwardhan et al. 2014; Simpson 2010; Tamura et al. 2011). Comparison between algorithm methods used a bootstrapping value of 1000 replications to test the validity of phylogenetic tree topology. The category of bootstrapping values are high $(>85 \%)$, moderate $(70-85 \%)$, weak $(50-69 \%)$, or very weak $(<50 \%)$ (Kress et al. 2002). Polymorphism of DNA sequences was analyzed by DnaSP ver. 5.10.01 statistic program. The aim of this analysis to know nucleotide bases changes. Results obtained showed that how much the Annonaceae species mutated.

\section{RESULTS AND DISCUSSION}

Polymorphism of DNA sequences from trnL molecular marker alignment shows that from 5 Annonaceae species of PBG, 10 species from GenBank and 2 Magnoliaceae 
species as the outgroup, there are 237 sites of nucleotide bases. Whereas, $145(61.18 \%)$ sites as a conserved region, $57(24.05 \%)$ sites as polymorphic variable and $35(14.76 \%)$ sites as alignment gaps or missing data (Table 2).

Popowia sp. is in group with $O$. enterocarpa, because DNA sequences of Popowia sp. was a transition as much as 3 characters. Nucleotides bases of Cytosine (C) was a transition to Tymine (T) on sites 65 , Adenine (A) was a transition to Guanine $(\mathrm{G})$ on sites 145 and $\mathrm{G}$ was transition to A on sites 204. M. javanica is in group with Oxymitra sp. and $F$. latifolium because nucleotide bases of $\mathrm{T}$ was insertion on sites 162 and 173, nucleotide bases of $C$ was insertion on sites 174 and 175, and nucleotide bases of $\mathrm{A}$ was insertion on sites 172, 176, 177 and 178. Changes of this nucleotide bases cause $M$. javanica genetically in group with Oxymitra sp. and $F$. latifolium, although morphologically it has a connate inner petal character where this character should be in group with $M$. polypyrena and Popowia sp. This is caused a missing data or alignment gaps.

\section{Species identity}

Results of DNA sequences show that the length of DNA sequences observed were ranged 524 to 553 bp linear DNA. The highest DNA sequences length was $M$. javanica, and the lowest DNA sequences length was Oxymitra sp. The highest and the lowest of GC content percentage was F. latifolium (38.2\%) and M. javanica $(36.3 \%)$. The range of identity percentage was about $93-99 \%$ (Table 3). It means that DNA sequences which were obtained are similar to materials plant species and the possibility of wrong identification in PBG, especially for unidentified species. Species identity of $M$. javanica from BLAST show 93\% similarity, this means that BLAST result for this species was not similar to species observed. Results of BLAST sequences DNA was aimed to estimate of species identity from the materials plant species were observed and would be submitted in the GenBank. Samples of DNA alignment was shown in Figure 2.

\section{Taxonomical position}

Results of cluster analysis from the phylogenetic tree with Maximum Parsimony (MP) analysis method (Figure 3) show that cladogram has a solid and congruent formation of the clade. However, the position of $M$. javanica on the group of a clade is less precise, and should be in the group with M. polypyrena. Oxymitra sp. should be in group with Annonoideae sub-family, not in group with $F$. latifolium. This grouping is applied based on the morphological character, due to $M$. javanica and $M$. polypyrena have connate inner petal whereas Oxymitra sp. and F. latifolium petals are free (Irawan 2002; Moeljono 2009; Weerasooriya and Saunders 2010a; Lestari et al. 2017). According to DNA sequences character, $M$. javanica is in group (monophyletic) with Oxymitra sp. and $F$. latifolium because they are genetically in close relationship (Uvariae tribes and Annonoideae sub-family). Popowia sp. is in group (monophyletic) with $O$. enterocarpa, because they are genetically in close relationship (Miliuseae tribes and Malmeoideae sub-family).

\section{Discussion}

Based on Chatrou et al. (2012), plant species materials are not similar identity from results of BLAST sequences DNA. Mitrephora is included in Miliuseae tribes and Malmeoideae sub-family, while Friesodielsia included in Uvariae tribes and Annonoideae sub-family. Fissistigma and Uvaria show the appropriate results of BLAST sequence included in Uvariae tribes and Annonoideae subfamily, Popowia, Polyalthia, and Mitrephora are included in Miliuseae tribes and Malmeoideae sub-family. Oxymitra is synonym with Friesodielsia while Cyathostemma is synonym with Uvaria. Friesodielsia and Uvaria are included in Uvariae tribes and Annonoideae sub-family. Incongruity from materials plant species with the results of BLAST DNA sequences is caused by unclear morphological character identification in the field, so was needed confirmation with molecular data and recently name that changes have not been upgraded.

Table 2. Polymorphism of DNA sequences from trn L molecular marker alignment

\begin{tabular}{|c|c|c|}
\hline $\begin{array}{c}\text { Polymorphism of DNA } \\
\text { sequences }\end{array}$ & $\begin{array}{c}\text { Total of } \\
\text { nucleotide bases }\end{array}$ & Position of nucleotides bases \\
\hline Conserved & 145 & $\begin{array}{l}1,2,4,5,6,7,8,11,12,14,16,17,18,19,20,21,22,23,24,25,26,27,28,29,30, \\
31,32,33,34,35,36,37,38,39,40,41,42,43,44,47,48,49,50,51,52,53,54, \\
56,57,58,59,61,62,68,69,70,71,73,74,75,76,77,86,87,88,89,90,91,92, \\
93,94,95,96,98,99,101,102,103,105,107,108,109,110,111,112,113,115, \\
116,117,118,119,123,124,125,127,128,129,130,131,134,135,137,139,142, \\
143,144,147,148,149,150,151,156,157,159,160,161,181,185,186,187,190, \\
191,193,198,199,201,205,207,208,209,210,211,213,214,215,216,219,226, \\
228,229,232,233,234,235,236,237\end{array}$ \\
\hline $\begin{array}{l}\text { Singleton variabel } \\
\text { (2 variants) }\end{array}$ & 25 & $\begin{array}{l}9,63,64,65,67,72,97,100,120,121,133,138,179,182,183,184,189,197,200 \\
202,204,206,212,217,227\end{array}$ \\
\hline \multicolumn{3}{|l|}{ Parsimony informative } \\
\hline-2 variants & 25 & $\begin{array}{l}10,13,15,60,66,104,106,114,122,126,132,136,140,141,146,152,155,158, \\
188,192,194,203,218,220,231\end{array}$ \\
\hline-3 variants & 6 & $3,145,153,154,196,230$ \\
\hline-4 variants & 1 & 180 \\
\hline
\end{tabular}


Table 3. Results of BLAST DNA sequences from PBG plant species

\begin{tabular}{lll}
\hline \multicolumn{1}{c}{ Species } & \multicolumn{1}{c}{ Species identity from BLAST } & $\%$ identity \\
\hline Fissistigma latifolium (Dunal) Merr. & Uvaria wrayi (King) L.L. Zhou, Y.C.F. Su \& R.M.K. Saunders & 99 \\
Magnolia candolli (Blume) H. Keng & Magnolia lilififera (L.) Baill. & 99 \\
Michelia champaca L. & Magnolia laevifolia (Y.W. Law \& Y.F. Wu) Noot & 99 \\
Mitrephora javanica Backer & Friesodielsia desmoides (Craib) Steenis & 93 \\
Mitrephora polypyrena Miq. & Mitrephora keithii Ridl. & 99 \\
Oxymitra sp. & Cyathostemma viridiflorum Griff. \\
Popowia sp. & Polyalthia littoralis (Blume) Boerl. \\
& \\
\hline
\end{tabular}

Species/Abbrv

1. Mitrephora_javanica

2. Fissistigma_latifolium

3. Mitrephora_polypyrena

4. Popowia_sp.

5. Oxymitra_sp.

6. Michelia_champaca

7. Magnolia_candolli

8. Cananga_odorata

9. Anaxagorea_javanica

10. Anaxagorea_luzonensis

11. Artabotrys_hexapetalus

12. Goniothalamus_macrophy1lus

13. Annona_montana

14. Annona_glabra

15. Goniothalamus_malayanus

16. Orophea_enterocarpa

17. Annona muricata

Species/Abbrv

1. Mitrephora_javanica

2. Fissiatigma latifolium

3. Mitrephora_polypyrena

4. Popowia_sp.

5. Oxymitra_sp.

6. Michelia_champaca

7. Magnolia_candolli

8. Cananga_odorata

9. Anaxagorea javanica

10. Anaxagorea_luzonengis

11. Artabotrys hexapetalus

12. Goniothalamus macrophyllus

13. Annona_montana

14. Annona glabra

15. Goniothalamus_malayanus

16. Orophea enterocarpa

17. Annona_muricata

1. Mitrephora_javanica

2. Fissistigma_latifolium

3. Mitrephora_polypyrena

4. Popowia sp.

5. Oxymitra_sp.

6. Michelia_champaca

7. Magnolia_candolli

8. Cananga_odorata

9. Anaxagorea javanica

10. Anaxagorea_luzonensis

11. Artabotrys hexapetalus

12. Goniothalamus_macrophy1lus

13. Annona_montana

14. Annona glabra

15. Goniothalamus_malayanus

16. Orophea enterocarpa

17. Annona_muricata

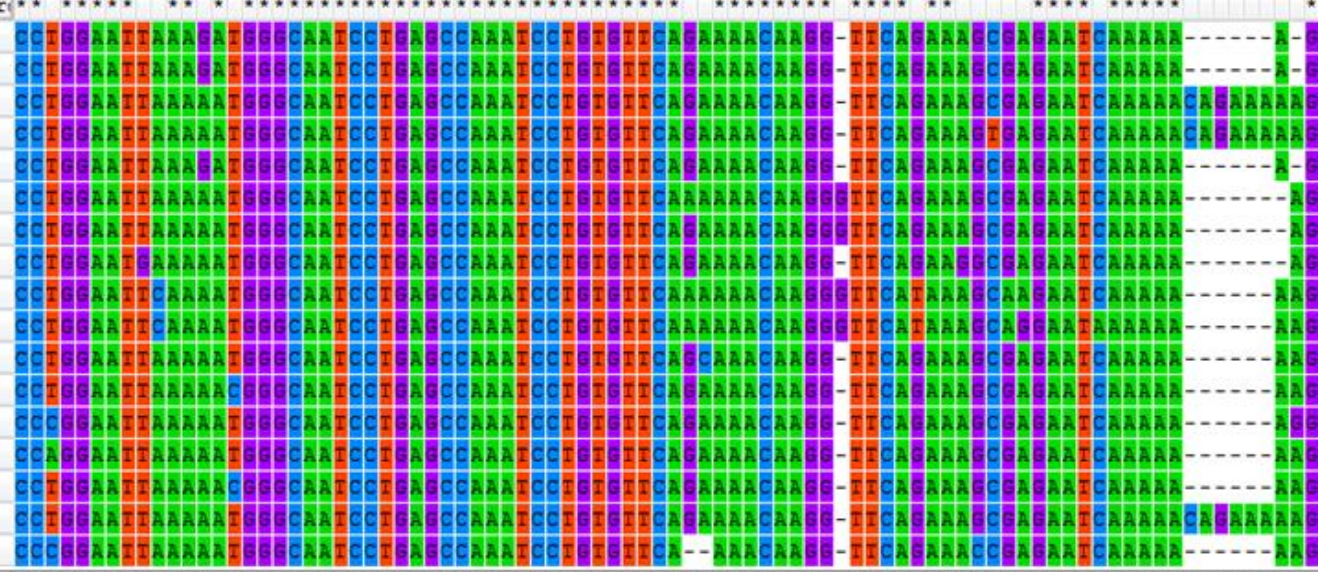

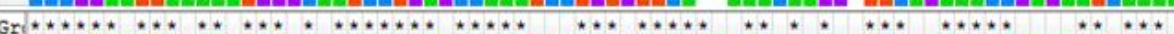

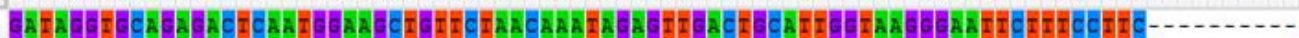

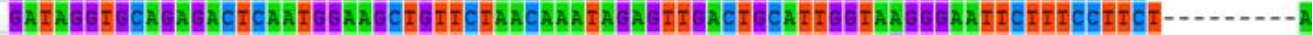

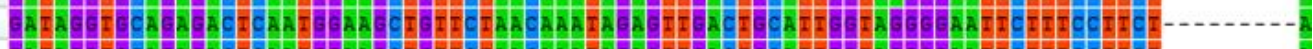

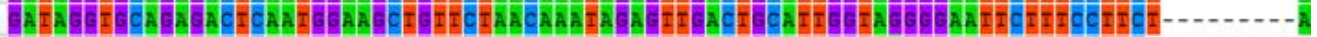

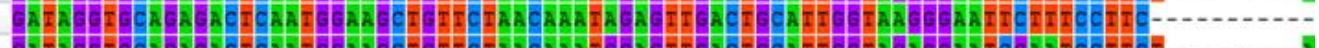

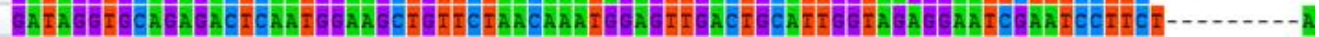

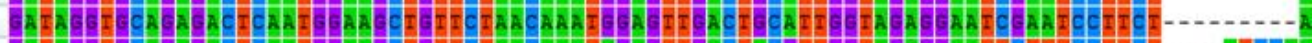

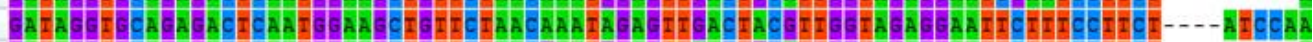

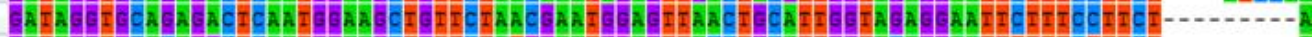

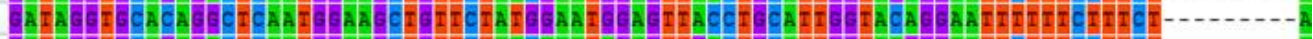

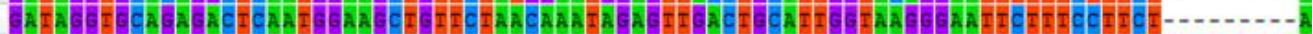

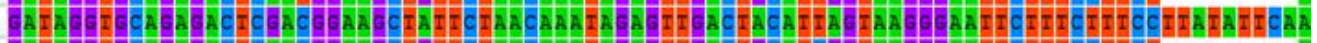

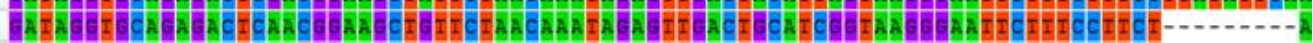

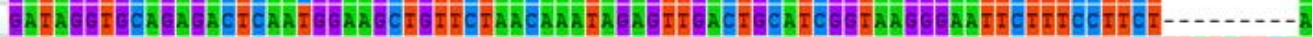

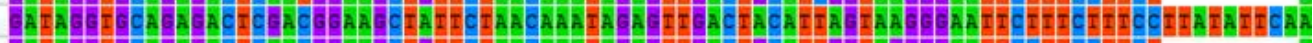

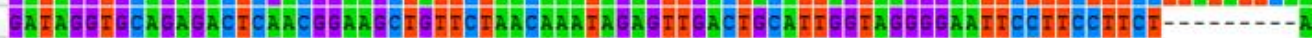

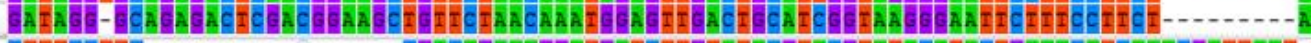

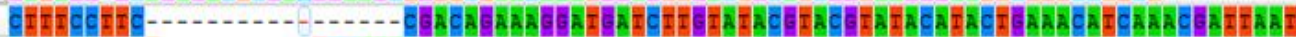

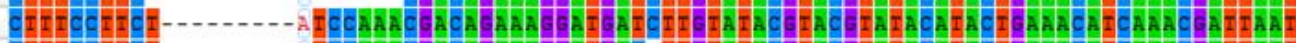

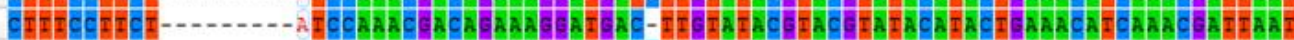

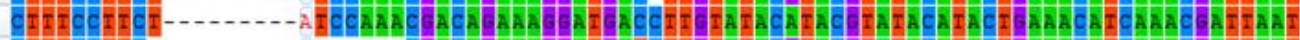

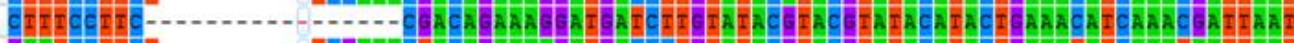

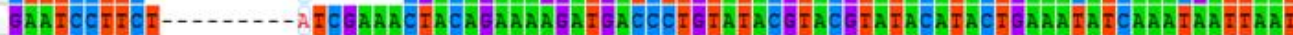

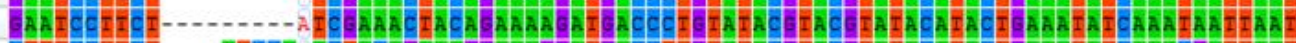

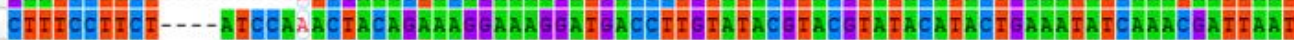

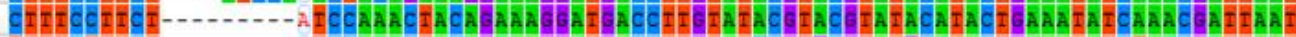

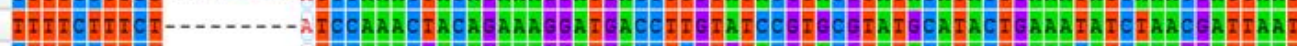

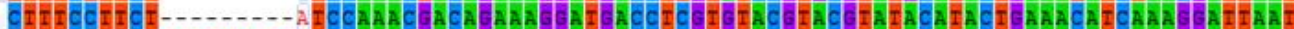

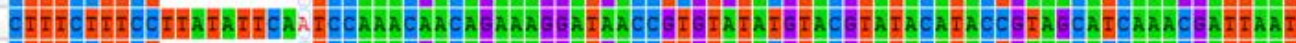

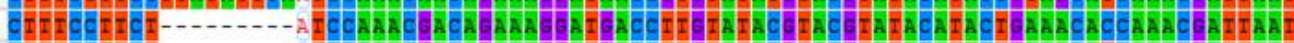

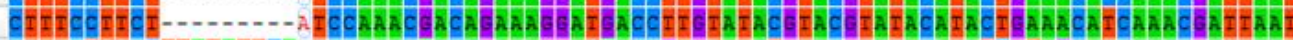

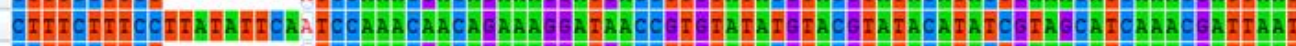

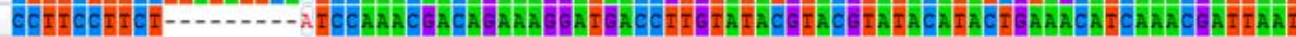

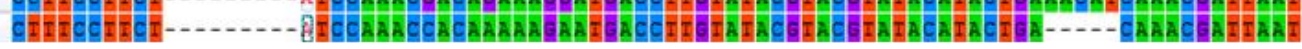

Figure 2. Samples of DNA alignment of material samples 


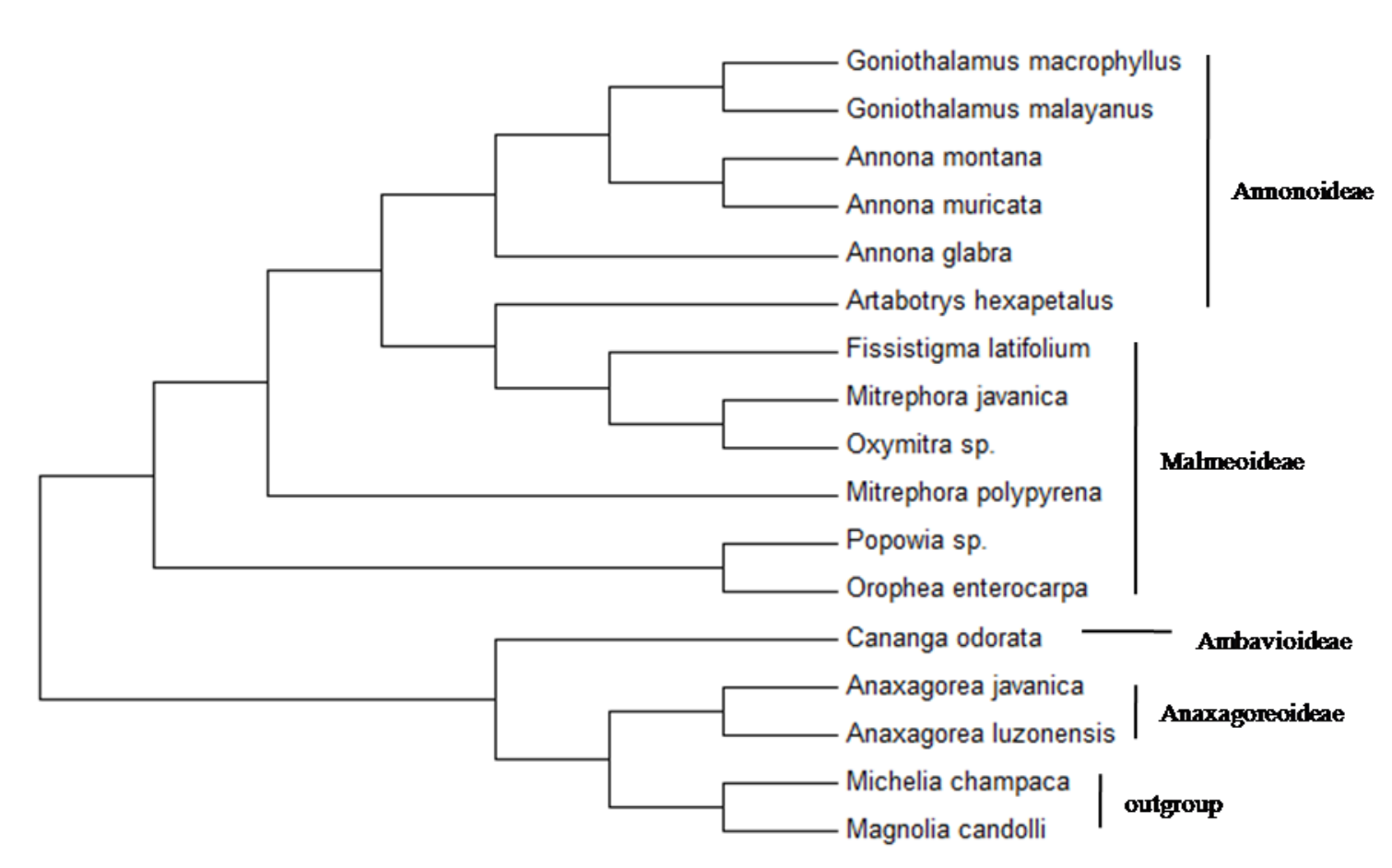

Figure 3. Taxonomical position based on $\operatorname{trn} \mathrm{L}$ molecular marker with algorithm method of Maximum Parsimony with bootstrap value 1000 replications

Friesodielsia desmoides is a small tree or shrub that is distributed in Africa and Asia, and grown as an ornamental plant. This plant has two synonym names, i.e. Goniothalamus desmoides and Oxymitra desmoides. Colour of the flower is yellow with connate inner petal and size of the outer petal is longer than inner petal (Meesakul et al. 2017). In PBG, this species is identified as $M$. javanica. Morphologically, $M$. javanica has a connate inner petal, the color of inner petal is pale yellow and the color of flower is white with the purple spot (Figure 1). The material sample of $M$. javanica is not matched with the results of BLAST DNA sequences. In the same case, $F$. latifolium is different to $U$. wrayi based on morphological character. $F$. latifolium has simple hairs and inner petals slightly equal or smaller than outer but $U$. wrayi has stellate hairs and inner petal has equal with outer (Irawan 2002; Irawan and Guhardja 2003; Zhou et al. 2009). Same as $M$. javanica, this species is not matched with the results of BLAST DNA sequences. The other species, genus of Popowia strongly supports its monophyly with Polyalthia. The asymmetrical leaf base usually characterizes the species of Popowia and Polyalthia, but they are differentiated in patterns of secondary leaf venation and the numbers of ovules per carpel (Xue et al. 2012; Ngoc et al. 2016). Results of BLAST DNA sequences are correctly identified to species name for Popowia sp.

Another example, Cyathostemma is synonym with Uvaria. This genus is characterized by small petals, globose buds, and petals not expanding or reflexing (Utteridge 2000). Cyathostemma and Oxymitra have similar habitus which is a woody climber but differentiated in hairs of petiole or midvein in the leaves. Cyathostemma has stellate hairs but Oxymitra has glabrous (no hairs). Same as $M$. javanica and $F$. latifolium, this species is not matched with the results of BLAST DNA sequences. The last example is $M$. polypyrena, which has cream turning bright yellow of the outer petal with cream, reddish or purplish lines of the inner petal, but $M$. keithii has yellow of outer petal and yellow with pink margins of the inner petal (Weerasooriya and Saunders 2010b). This shows that trn $\mathrm{L}$ sequence was suitable for genus level and not for species level, especially for genus of Mitrephora.

The trn $\mathrm{L}$ sequence presents a perception of other groupings that may differ from previous groupings, because this sequence contains genes that are not directly related to the petal expressions in which petal characters are morphological characters that have been used as taxonomic markers for the classification of the Annonaceae group. Based on that, only $30 \%$ are correctly identified species name from 5 species were observed based on this sequence. This indicates that more sequences were needed to confirm the species name identification, because certain sequence did not applicate to the other species in one family. So, the success of species name identification not only in taxa that observed but also in the utilized marker (Amandita 2015).

Monophyletic groups are considered to have very close relationships and assumed to carry the same genetic or biochemical traits or patterns (Hidayat and Pancoro 2008; Rahayu and Nugroho 2015). Alignment gaps or missing data are the presence of mutations insertion-deletion interspecies and the most influential to identity of the 
species (Hollingsworth et al. 2011). Variable polymorphic sites consist of singletons variable (25 sites) and parsimony informative (25 sites). Singleton variable is variations where there is only one position of a different nucleotide from one OTU (Operational Taxonomical Unit) (Hidayat and Pancoro 2008). Singleton variable is autopomorphic character, where DNA sequences character only belongs to certain species. Generally, these species are more adaptive to the specific habit than the other species. Parsimony informative is the character of DNA sequences that at least has 2 types of nucleotide bases and both of them must appear at least twice in that position (Yingzhi et al. 2007).

The DNA sequence of $\operatorname{trn} \mathrm{L}$ as non-coding gene presents a perception of other groupings that may differ from previous groupings in Annonaceae, especially species on this study. This sequence can estimate the identity of species as much as $30 \%$ correctly. The taxonomical position of 5 species of Annonaceae are observed was influenced by changes in nucleotide bases.

\section{ACKNOWLEDGEMENTS}

The author would like to acknowledge Risca Adiyani Rachma for helping during laboratory research and Abban Putri Fiqa for helping review of spell and grammar checked.

\section{REFERENCES}

Amandita FY. 2015. DNA Barcoding of Flowering Plants in Jambi, Indonesia. [Dissertation]. Georg-August Universitat of Gottingen, Germany.

Chaowasku T, Keßler PJA. 2013. Phylogeny of Miliusa (Magnoliales: Annonaceae: Malmeoideae: Miliuseae), with descriptions of two new species from Malesia. Eur J Taxon 54: 1-21.

Chatrou LW, Pirie MD, Erkens RHJ, Couvreur TLP, Neubig KM, Abbott RJ, Mols JB, Maas JW, Saunders RMK, Chase MW. 2012. A new subfamily and tribal classification of the pantropical flowering plant family Annonaceae informed by molecular phylogenetics. Bot J Linn Soc 169: 5-40.

Couvreur TLP. 2009. Monograph of the syncarpous African genera Isolona and Monodora (Annonaceae). Syst Bot Mon 87: 1-150.

Doyle JA, Le Thomas A. 1996. Phylogenetic analysis and character evolution in Annonaceae. Bulletin du Muséum National d'Histoire Naturelle, Paris, 4e série, Section B, Adansonia 18: 279-334.

Fatchiyah, Arumingtyas EL, Widyarti S, Rahayu S. 2011. Molecular Biology: Basic Principles of Analysis. PT Erlangga, Jakarta. [Indonesian]

Handayani T. 2016. Flowering and fruiting time of Annonaceae species in Bogor Botanic Gardens. Buletin Kebun Raya 19 (2): 91-104. [Indonesian]

Hidayat T, Pancoro A. 2008. The study of molecular phylogenetics and its role in providing basic information to improve the quality of genetic resources of orchids. Jurnal AgroBiogen 4 (1), 35-40. [Indonesia]

Hollingsworth PM, Graham SW, Little DP. 2011. Choosing and using a plant DNA barcode. PLOS ONE 6 (5): e19254. DOI: 10.1371/journal.pone.0019254.

Huysmans S, Verstraete B, Smets E, Chatrou LW. 2010. Distribution of orbicules in Annonaceae mirrors evolutionary trend in angiosperms. Pl Ecol Evol 143: 199-211.

Hutchinson J. 1969. Evolution and Phylogeny of Flowering Plants (Angiospermae). Volume 2. Clarendon Press, Oxford

Irawan B. 2002. Malesian species of Fissistigma (Annonaceae). Floribunda 2: 1-23. [Indonesian]

Irawan B, Guhardja E. 2003. Taxonomy study of Fissistigma Griff. (Annonaceae) in Java. Jurnal Biotika 2 (1): 1-7. [Indonesian]
Johnson DM. 2003. Phylogenetic significance of spiral and distichous architecture in the Annonaceae. Syst Bot 28: 503-511.

Johnson DM, Murray NA. 1995. Synopsis of the tribe Bocageeae (Annonaceae), with revisions of Cardiopetalum, Froesiodendron, Trigynaea, Bocagea, and Hornschuchia. Brittonia 47: 248-319.

Kessler PJA. 1995. Subdivision and relationships of the Asiatic Australian genus of Annonaceae. Rheedea 5: 97-102.

Kishor R, Sharma GJ. 2018. The use of the hypervariable P8 region of $\operatorname{trnL}$ (UAA) intron for identification of orchid species: evidence from restriction site polymorphism analysis. PloS ONE 13 (5): e0196680 https: //doi.org/10.1371/journal.pone.0196680.

Kojoma M, Kurihara K, Yamada K, Sekita S, Satake M, Iida O. 2002. Genetic identification of cinnamon (Cinnamomum spp.) based on the trnL-trnF chloroplast DNA. Planta Med 68: 94-96.

Kress WJ, Prince LM, Williams KJ. 2002. The phylogeny and a new classification of the gingers (Zingiberaceae): evidence from molecular data. Ann J Bot 89: 1682-1696.

Kwon O, Park Y, Kim H, Kong W, Cho J, Lee C. 2016. Taxonomic position and species identity of the cultivated Yeongji Ganoderma lucidum in Korea. Mycobiology 44 (1): 1-6.

Lestari DA, Azrianingsih R, Hendrian. 2017. Taxonomical position of Annonaceae species from East Java, Indonesia: collections of Purwodadi Botanic Garden based on morphological character. Biodiversitas 18 (3): 1067-1076

Lestari DA, Azrianingsih R, Hendrian. 2018. Phylogenetics of Annonaceae species from East Java collections of Purwodadi Botanic Garden based on coding and non-coding sequence DNA. J. Trop. Biodiv. Biotech. 3: 1-7. [Indonesian]

Li PS, Thomas DC, Saunders RM. 2015. Phylogenetic reconstruction, morphological diversification and generic delimitation of Disepalum (Annonaceae). PloS One 10 (12): e0143481. DOI: 10.1371/journal.pone.0143481.

Maas PJM, Westra LYT. 1984. Studies in Annonaceae. II. A monograph of the genus Anaxagorea A.St.Hil., part 1. Bot Jahr Syst Pflan Pflanz 105: 73-134.

Maas PJM, Westra LYT, Chatrou LW. 2003. Duguetia. Flora Neotropica Monograph 88. The New York Botanical Garden, New York.

Maas PJM, Westra LYT, Vermeer M. 2007. Revision of the Neotropical genera Bocageopsis, Onychopetalum, and Unonopsis (Annonaceae). Blumea 52: 413-554.

Meesakul P, Pudhom K, Pyne GP, Laphookhieo S. 2017. Hybrid flavanflavanones from Friesodielsia desmoides and their inhibitory activities against nitric oxide production. RSC Adv. 7: 17545-17550. DOI: $10.1039 / \mathrm{c} 7 \mathrm{ra02528a.}$

Moeljono S. 2009. A Taxonomic Revision of The Genus Popowia Endlicher (Annonaceae) in Malesia. [Dissertation]. Bogor Agricultural University, Bogor.

Morawetz W, Le Thomas A. 1988. Karyology and systematics of the genus Ambavia and other Annonaceae from Madagascar. Pl Syst Evol 158: $155-160$.

Ngoc NV, Tagane S, Binh HT, Toyama H, Okabe N, Duy CN, Yahara T. 2016. Popowia bachmaensis (Annonaceae), a new species from Bach Ma National Park, Central Vietnam. PhytoKeys 65: 125-131.

Patwardhan A, Ray S, Roy A. 2014. Molecular markers in phylogenetic studies-A review. Phyl Evol Biol 2 (2): 1-9. DOI: 10.4172/2329. 9002.1000131

Procaccini G, Mazzella L, Alberte RS, Les DH. 1999. Chloroplast tRNA $^{\text {Leu }}$ (UAA) intron sequences provide phylogenetic resolution of seagrass relationships. Aquat Bot 62: 269-283.

Rachma RA, Hendrian, Azrianingsih R. 2017. The analysis of Pandanus relationship of Purwodadi Botanical Garden collections based on morphological character and molecular marker (trn $\mathrm{L}$ and $\operatorname{trn} \mathrm{L}-\mathrm{F})$. RJLS 4 (2): 129-142.

Rahayu DA, Nugroho ED. 2015. Molecular Biology on Conservation Perspective. Plantaxia, Yogyakarta. [Indonesian]

Rosidiani EP. 2011. Genetic Variation in Some Populations of Porang in Eastern Java Based on intron trnL. [Thesis]. Brawijaya University, Malang. [Indonesian]

Scharaschkin T, Doyle JA. 2005. Phylogeny and historical biogeography of Anaxagorea (Annonaceae) using morphology and non-coding chloroplast sequence data. Syst Bot 30: 712-735.

Scharaschkin T, Doyle JA. 2006. Character evolution in Anaxagorea (Annonaceae). Am J Bot 93: 36-54.

Simpson MG. 2010. Plant Systematics. 2nd ed. Academic Press, USA.

Stackebrandt E, Goebel BM. 1994. Taxonomic note: a place for DNADNA reassociation and $16 \mathrm{~S}$ rRNA sequence analysis in the present 
species definition in bacteriology. Int J Syst Bacteriol 44 (4): 846849.

Su YCF, Saunders RMK. 2006. Monograph of Pseuduvaria (Annonaceae). Syst Bot Mon 79: 1-204.

Surveswaran S, Wang RJ, Su YCF, Saunders RMK. 2010. Generic delimitation and historical biogeography in the early-divergent 'ambavioid' lineage of Annonaceae: Cananga, Cyathocalyx and Drepananthus. Taxon 59: 1721-1734.

Svoma E. 1998. Studies on the embryology and gynoecium structures in Drimys winteri (Winteraceae) and some Annonaceae. Pl Syst Evol 209: 205-229.

Taberlet P, Coissac E, Pompanon F, Gielly L, Miquel C, Valentini A, Vermat T, Corthier G, Brochmann C, Willerslev E. 2007. Power and limitations of the chloroplast $\operatorname{trn} \mathrm{L}$ (UAA) intron for plant DNA barcoding. Nucleic Acids Res 35 (3): e14-e21. DOI 10.1093/nar/gk1938.

Tamura K, Peterson D, Peterson N, Stecher G, Nei M, Kumar S. 2011. MEGA 5: Molecular evolutionary genetics analysis using maximum likelihood, evolutionary distance and maximum parsimony methods. Mol Biol Evol 28 (10): 2731-2739.

Tang CC, Thomas DC, Saunders RMK. 2015a. Molecular phylogenetics of the species-rich angiosperm genus Goniothalamus (Annonaceae) inferred from nine chloroplast DNA regions: synapomorphies and putative correlated evolutionary changes in fruit and seed morphology. Mol Phyl Evol 92: 124-139.

Tang CC, Thomas DC, Saunders RMK. 2015b. Molecular and morphological data supporting phylogenetic reconstruction of the genus Goniothalamus (Annonaceae), including a reassessment of previous infrageneric classifications. Data Brief 4: 410-421. DOI: 10.1016/j.dib.2015.06.021.

Tsai L, Yu Y, Hsieh H, Wang J, Linacre A, Lee J. 2006. Species identification using sequences of the $\operatorname{trn} \mathrm{L}$ intron and the $\operatorname{trn} \mathrm{L}-\operatorname{trn} \mathrm{F}$ IGS of chloroplast genome among popular plants in Taiwan. Forensic Sci Int 164: 193-200.

Tsou CH, Johnson DM. 2003. Comparative development of aseptate and septate anthers of Annonaceae. Am J Bot 90: 832-848.
Utteridge TMA. 2000. Revision of the genus Cyathostemma (Annonaceae). Blumea 45: 377-396.

van Heusden. 1992. Flowers of Annonaceae: morphology, classification, and evolution. Blumea Suppl 7: 1-218.

van Setten AK, Koek-Noorman J. 1992. Studies in Annonaceae. XVII. Fruits and Seeds of Annonaceae: Morphology and Its Significance for Classification. Schweizerbart'sche Verlagsbuchhandlung, Stuttgart.

Wahyudi D, Azrianingsih R, Mastuti R. 2013. Genetic variability of porang populations (Amorphophallus muelleri) in West Java and Central Java based on trnL intron sequences. JBES 3 (9): 31-41.

Weerasooriya AD, Saunders RMK. 2010a. Monograph of Mitrephora (Annonaceae). Syst Bot Mon 90: 1-167.

Weerasooriya AD, Saunders RMK.2010b. Systematic Botany Monographs of Mitrephora (Annonaceae). Volume 90. The American Society of Plant Taxonomists, United States of America.

Westra LYT. 1985. Studies in Annonaceae. IV. A taxonomic revision of Tetrameranthus R.E.Fries. Proceedings of the Koninklijke Nederlandse Akademie van Wetenschappen, Series C 88: 449-482.

Xue B, Yvonne CFS, Thomas DC, Saunders RMK. 2012. Pruning the polyphyletic genus Polyalthia (Annonaceae) and resurrecting the genus Monoon. Taxon 61: 1021-1039.

Yingzhi L, Yunziang C, Nengguo T, Xiuxin D. 2007. Phylogenetic analysis of mandarin landraces, wild mandarin and related species in China using nuclear LEAFY second intron and plastid trnL-trnF sequence. J Am Soc Horti Sci 132 (6): 796-806.

Yulita KS. 2013. Secondary structures of chloroplast trn L intron in Dipterocarpaceae and its implication for the phylogenetic reconstruction. Hayati J Biosci 20 (1): 31-39.

Zhou L, Su YCF, Saunders RMK. 2009. Molecular phylogenetic support for a broader delimitation of Uvaria (Annonaceae), inclusive of Anomianthus, Cyathostemma, Ellipeia, Ellipeiopsis and Rauwenhoffia. Syst Biodiv 7 (3): 249-258.

Zhou L, Su YCF, Chalermglin P, Saunders RMK. 2010. Molecular phylogenetics of Uvaria (Annonaceae): relationships with Balonga, Dasoclema and Australian species of Melodorum. Bot J Linn Soc 163: 33-43. 